\title{
Ethical Climate, Job Satisfaction and Organizational Commitment of Hotel Employees
}

\author{
Carmen C. Menes ${ }^{1}$ and Ismael A. Haguisan III $^{2}$ \\ 1, 2 La Consolacion College-Bacolod, Bacolod City, Philippines
}

\section{Article history:}

Submitted: 22 June 2020

Revised: 23 November 2020

Accepted: 31 December 2020

\section{Keywords:}

Business management

Hotel ethical climate

Job satisfaction

Organizational commitment

Descriptive-correlational

Philippines

\begin{abstract}
Ethical climate in the workplace has a relationship with job satisfaction and organizational commitment; thus, influencing organizational productivity. This descriptive-correlational study confirmed the relationship between ethical climate, job satisfaction, and hotel employees' organizational commitment. Using stratified random sampling proportionate allocation, 152 employees from two hotels with the same owner and management were identified as respondents. An adapted-modified survey questionnaire was used to collect the data. Mean, standard deviation, and Pearson $r$ were used to analyze the data. The employees in the standard class hotels perceived an ethical work environment. They were slightly satisfied and committed to their job. Their perceived ethical climate showed a significant relationship with job satisfaction and organizational commitment. The management may explore various ways to improve the ethical climate, job satisfaction, and organizational commitment of employees to attain higher productivity.
\end{abstract}

\subsection{Introduction}

Supervisors and coworkers are among the influential fundamental factors in employees' social behavior (Chiaburu \& Harrison, 2008; Stanley, 2016) where they look at others in their organization to determine appropriate, acceptable, and ethical behavior (Cremer, Mayer, \& Schminke, 2010; Potocan, Mulej, \& Nedelko, 2013) especially when uncertainty is high (Mayer, Nurmohamed, Treviño, Shapiro, \& Schminke, 2013).

Ethical climate leads to a working environment that improves moral values (Uen, Wu, \& Tsai, 2011) and gives a definite direction for decision making in ethical circumstances enabling individuals to enjoy their works (Nafei, 2015). Undesirable climates, reflecting a productive environment connected with egoism, were related to staff turnover, absenteeism, stealing, lying, falsifying reports, and accepting gifts (Armstrong \& Francis, 2008; Nafei, 2015), whereas the opposite characterizes a more ethical organizational climate (Peterson, 2002).

A significant positive relationship exists, linking ethical climate and organizational commitment (Bernaldez \& Gempes, 2016; Ma'amor, Ann, Munir, \& Hashim, 2013; Putra, Dharmanegara, \& Yas, 2019). Asian business community looked at higher levels of organizational commitment associated with employee's perception of their organization's ethical climate as caring and principle-based (Ismail, 2015).

Ethical climate influences job satisfaction (Anaza, Rutherford, Rollins, \& Nickell, 2015; Jaramillo, Mulki, \& Solomon, 2006; Nafie, 2015; Pettijohn, Pettijohn, \& Taylor, 2008; Putra et al., 2019) and organizational commitment (Armstrong \& Francis, 2008; Nafie, 2015). A significant positive association between moral climate and job satisfaction may propel an ethical climate required to create the positive side of employees' attitudes, which can drive greater job satisfaction (Emmanuel \& Oge, 2016).

Commitment relates to ethical work climate (Mayer, Nurmohamed, Treviño, Shapiro \& Schminke, 2013; Putra et al., 2019). A favorable ethical climate exists in an organization when employees believe that ethical norms guide decision-making (Cullen, Parboteeah, \& Victor, 2003;Rubel et al., 2017). As an organization's ethical climate advances, personnel develops a sense of commitment (Rabiul, Kee, Quah, Rimi, 2017).

This study determined the relationship between employees' hotel ethical climate, job satisfaction, and organizational commitment. Specifically, the study sought to determine the ethical climate, job satisfaction, and organizational commitment of the selected standard class hotels as perceived by their employees when grouped according to age, sex, length of service, and when taken collectively. Furthermore, the study intended to determine if ethical climate significantly relates to job satisfaction and organizational commitment of employees of two standard class hotels with the same owner and management. This study may help address the limited studies on the connection between ethical climate, job satisfaction, and organizational commitment in the Philippine setting, particularly in the 
hospitality industry. Moreover, this study may contribute to the hotel industry by providing valuable information regarding ethical business practices that can propel satisfied and committed employees.

\subsection{Framework of the Study}

The researchers referred to the social exchange theory, one of the most influential conceptual paradigms in management (Cropanzano, Anthony, Daniels, \& Hall, 2017), specifically in understanding workplace behavior (Chou, 2016; Cropanzano \& Mitchell, 2005). The theory suggests that when a person provides another person a reward, resource, or another commodity, there is an expectation of anticipated return from another party (Bernerth \& Walker, 2009). Moreover, it provides conceptual underpinnings for understanding employees' workplace attitudes and can explain the employee's positive outcomes (Chiu \& Ng, 2013).

The concepts on ethical climate, organizational commitment, and job satisfaction were explained in this study based on the social exchange theory and a combination of related concepts, thus, credible results for the study. When the employees are provided with policies and guidelines to follow (based on ethical climate), there is an expectation of anticipated behavioral response (job satisfaction and organizational commitment).

The ethical climate is a kind of work climate reflecting the organizational procedures, policies, and practices with moral consequences that constitutes the right behavior (Martin \& Cullen, 2006). Initially, in 1987, Victor and Cullen described the ethical climate as 'the shared perception of what is right behavior, and how ethical situations should be handled' as presented by Yener, Yaldıran, and Ergun (2012), who measured ethical climate in three dimensions, namely, social responsibility, rules, and professional codes and personal morality. Organizations play an essential role in forming employees' ethical behavior (Newman, Round, Bhattacharya, \& Roy, 2017).

Older employees possess higher ethical values than younger workers (Aprilliani, Anggaraini, \& Anwar, 2014; Cheteni, \& Shindika, 2017; Verschoor, 2013). Mature employees tend to be more cooperative in complying with statutory and regulatory requirements and are more likely to stick by hotel rules and regulations since the ethical climate partly represents policies and procedures (Arulrajah, 2015).

When employees perceive their organization is ethical, they are more likely to stay (Karatepe, 2013; Trevino, Butterfield, \& McCabe, 1998). In other words, employees with favorable perceptions of the firm's ethical climate are committed to their jobs (Karatepe, 2013).

The slightly ethical 'personal morality' among the employees of the hotel may trigger them to revert to unethical conduct, especially in times of crisis; however, to avoid this, the hotel management may have a code of ethics, as this plays a vital role in building an ethical culture (Graham, 2014). Thus, the hotel management needs to raise ethical awareness and sensitivity among its employees (Arulrajah, 2015).

Job satisfaction is the employees' pleasant emotional attitude (Putra et al., 2019), which results from his comparison of definite outcomes with desired, anticipated, or deserved in a particular job (Kim \& Miller, 2008; Oshagbemi, 1999) Job satisfaction can be viewed as an important empirical result of ethical work (Putra et al., 2019).

Age influence job satisfaction, and generally, older employees tend to experience higher levels of job satisfaction (Concialdi, 2014; Eleswed \& Mohammed, 2013; Hancer \& George, 2003), which may be due to the perks that come with maintaining a long career, including higher salaries, better benefits, and progress in the workplace (Iroegbu, 2015). Length of services or tenure is also a critical determinant of job satisfaction (Francis, 2015). Hotels are part of the service industry, and employees mainly provide most of their services (Hwang \& Seo, 2016). When hotel employees are satisfied with their jobs, they tend to deliver high-quality service to patrons (Hwang \& Seo, 2016; Kim, Ro, Hutchinson, \& Kwun, 2014; Kong, Cheung, \& Qiu Zhang, 2010).

The degree of an employee's identification with and involvement in his organization is a clear definition of organizational commitment coined by Mowday, Steers, and Porter in 1979 as presented by Al-Jabri and Ghazzawi (2019). Also, organizational commitment is a belief by an individual to work with his organization and labor effortlessly to survive (Azeez, Jayeoba, \& Adeoye, 2016; Kumar, Ramendran, \& Yacob, 2012).

Organizational commitment refers to an individual's desire to remain focused and attached to their work (Abdullah, 2011). It is measured through three scales: affective, normative, and continuance commitment (Meyer, Allen, \& Smith, 1993). Each of the three forms of commitment 
is equally important and useful. Affective commitment is an employee's attachment with his organization and its goals (O'Reilly \& Chatman, 1986). Continuance commitment is associated with an employee's organizational commitment because of the work-relationships and other benefits (Abdullah, 2011). In contrast, normative commitment reflects commitment based on its perceived obligation (Jaros, 2007).

According to Mathieu and Zajac (1990), older employees will have fewer job opportunities, leading to a higher commitment to their current jobs (Chiew, Foo, Ho, Hu, \& Tan, 2014). With longer stays, employees realize that moving away may cost them more than staying (Parasuraman \& Nachman, 1987). Women had higher organizational commitment levels and continuance commitment than men suggesting differences in perceived organizational commitment dimensions (Clayton, Petzall, Lynch, \& Margret, 2007; Jonathan, 2013).

From various perspectives described above, the researchers' proposition is that job satisfaction and organizational commitment result from ethical climate and can be described using the following diagram:

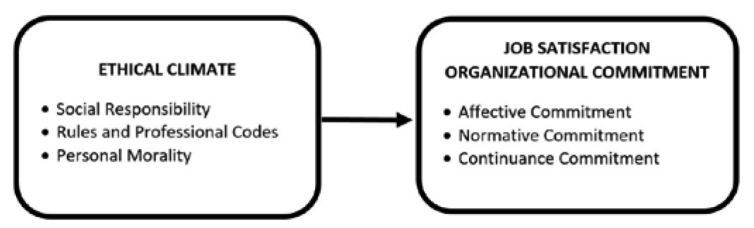

\subsection{Methods}

The researchers used descriptive-correlational design. It is the most appropriate design to use for studies that aim to find out conditions, perceptions, beliefs, processes, effects, and developing trends, such as in this study (Punch, 2013).

From the total number of rank and file employees (251), Cochran's formula was used to determine the sample size of 152 respondents identified using stratified random samplingproportionate allocation.

Data were collected using a consolidated survey questionnaire adapted from Cullen, Victor, \& Bronson (1993) for the ethical climate (18 items), Yeh (1999) for job satisfaction (13 items), and Allen and Meyer (1990) for organizational commitment (18 items). The items for ethical climate and job satisfaction were slightly modified. Responses to the items were based on the following guide:

\begin{tabular}{cl|l|l}
\hline Scale & \multicolumn{2}{c}{ Verbal Description/Interpretation } \\
\hline & Ethical Climate & Job Satisfaction & Organizational Commitment \\
7 & Extremely Ethical & Extremely Satisfied & Strongly Agree/Extremely committed \\
6 & Ethical & Satisfied & Agree/Committed \\
5 & Slightly Ethical & Slightly Satisfied & Slightly Agree/Slightly Committed \\
4 & Undecided & Undecided & Undecided \\
3 & Slightly Unethical & Slightly Unsatisfied & Slightly disagree/Slightly Not Committed \\
2 & Unethical & Unsatisfied & Disagree/Not committed \\
1 & Very unethical & Very unsatisfied & Strongly disagree/Extremely not committed \\
\hline
\end{tabular}

The instrument was subjected to validity using content validity ratio ( $\mathrm{CVI}=0.953)$ (Ayre \& Scally, 2014) and reliability using Cronbach's alpha ( $\alpha=0.987$ for ethical climate; $\alpha=0.944$ for job; $\alpha=0.821$.

For the ethical considerations, the researchers requested the respondents sign the informed consent form, which served as proof of their willingness to participate. The purpose of the study, the respondents' rights, benefits, risks, and confidentiality of information were all stipulated in the informed consent form.

After validating the accuracy and completeness of the data collected, these were analyzed using the mean, standard deviation, and Pearson $r$. 


\subsection{Results and Discussion}

Ethical Climate. The older employees have a more cohesive response, which reveals an ethical climate. However, their younger counterparts had a more diverse response and perceived a slightly ethical climate in the hotels. This calls for the hotel management to identify key gaps resulting from such differences and use these as bases in designing programs and training, crafting policies and procedures to strengthen their ethical practices. Changing the behavior of younger employees through ethical culture and climate may significantly affect the hotel's performance and reputation.

Similarly, the studies of Cheteni and Shindika (2017), Aprilliani et al. (2014), and Verschoor (2013) found out that older employees possess higher ethical values compared to younger workers. Mature employees tend to be more cooperative in complying with statutory and regulatory requirements and are more likely to stick by hotel rules and regulations since these parts represent the hotel's ethical climate (Arulrajah, 2015).

However, it is interesting to note that Westermann-Behaylo (2010) found out that the ethical climate assessment is fairly stable as there is no variation across employees' age.

Table 1.1. Ethical climate of the hotel employees when grouped according to age

\begin{tabular}{llllllll}
\hline \multirow{2}{*}{ Factors } & \multicolumn{3}{c}{ Younger $(\mathrm{n}=85)$} & \multicolumn{3}{c}{ Older $(\mathrm{n}=67)$} \\
& $\overline{\mathrm{x}}$ & SD & Int & $\overline{\mathrm{x}}$ & SD & Int \\
\hline Social Responsibility & 5.15 & 1.43 & SE & 5.59 & 0.94 & $\mathrm{E}$ \\
Rules and Professional Codes & 5.10 & 1.63 & SE & 5.56 & 1.03 & $\mathrm{E}$ \\
Personal Morality & 5.01 & 1.65 & SE & 5.54 & 1.06 & $\mathrm{E}$ \\
Over-all Ethical Climate & 5.08 & 1.50 & SE & 5.56 & 1.00 & $\mathrm{E}$ \\
\hline
\end{tabular}

Note: Int=Interpretation, SE=Slightly Ethical, E=Ethical

Across all three factors, female employees have a better perception of the hotel's overall ethical climate. Considering this, the hotel management may incorporate ethical situation training to concentrate on the male and younger group. Perhaps they may benefit from such training and be motivated to make ethical decisions/actions.

Female employees tend to have higher ethical awareness than males (Brunton \& Eweje, 2012; Venezia, Nti-Osei, Venezia, \& Hsueh, 2017), are more ethically oriented (Mtonga-Monga \& Flotman, 2017), have higher personal business ethics scores (Mitonga-Monga \& Flotman, 2017; Mujtaba, Cavico, \& Sungkhawan, 2011) and exhibit enhanced ethical judgment capacity (Mc Danel de García, 2013). Females practice ethical responsibilities more (Longenecker, Moore, Petty, Palich, \& McKinney, 2006). They manifest a better moral character (Vrdoljak Raguž, \& Matić, 2016). Women have higher possibilities of maintaining ethical considerations than men (Cheteni, \& Shindika, 2017) who tend to be engaged in unethical behavior than women (Dawson, 1995).

However, according to Vrdoljak Raguž and Matić (2016), males have a higher regard for ethical attitudes than females, indicating a relatively higher attitude towards business ethics among males.

After all, another study revealed that males and females do not differ significantly in ethical decision-making (Costouros, 2017).

Table 1.2. Ethical climate of the hotel employees when grouped according to sex

\begin{tabular}{llllllll}
\hline \multirow{2}{*}{ Factors } & \multicolumn{3}{c}{ Male $(\mathrm{n}=74)$} & \multicolumn{4}{c}{ Female $(\mathrm{n}=78)$} \\
& $\overline{\mathrm{x}}$ & SD & Int & $\overline{\mathrm{x}}$ & SD & Int \\
\hline Social Responsibility & 5.11 & 1.40 & SE & 5.57 & 1.06 & $\mathrm{E}$ \\
Rules and Professional Codes & 5.03 & 1.55 & SE & 5.56 & 1.22 & $\mathrm{E}$ \\
Personal Morality & 5.02 & 1.64 & SE & 5.45 & 1.21 & $\mathrm{E}$ \\
Over-all Ethical Climate & 5.05 & 1.47 & SE & 5.53 & 1.11 & $\mathrm{E}$ \\
\hline
\end{tabular}

Note: Int=Interpretation, SE=Slightly Ethical, E=Ethical 
Employees with longer service consider the hotel an ethical climate. In comparison, those with a shorter service perceive that the hotels have a slightly ethical climate. The hotel management may consider the ethical climate as among the factors that helped them retain their employees. The slightly ethical personal morality among the employees may trigger unethical conduct, especially in crisis times. However, this may be prevented if the hotel management can develop with their code of ethics and develop/conduct training to raise the ethical awareness and sensitivity of employees with a shorter length of service.

Employees observing that the organization is ethical (Karatepe, 2013) and organizational policies, procedures, and practices are determined within an ethical context (Treviño et al., 1998) are more likely to stay in the organization.

Table 1.3. Ethical climate of the hotel employees when grouped according to length of service

\begin{tabular}{llllllll}
\hline \multirow{2}{*}{ Factors } & \multicolumn{3}{c}{ Shorter $(\mathrm{n}=89)$} & \multicolumn{3}{l}{ Longer $(\mathrm{n}=63)$} \\
& $\overline{\mathrm{x}}$ & SD & Int & $\overline{\mathrm{x}}$ & SD & Int \\
\hline Social Responsibility & 5.09 & 1.47 & SE & 5.71 & 0.73 & $\mathrm{E}$ \\
Rules and Professional Codes & 5.04 & 1.65 & SE & 5.56 & 0.87 & $\mathrm{E}$ \\
Personal Morality & 4.95 & 1.67 & SE & 5.65 & 0.91 & $\mathrm{E}$ \\
Over-all Ethical Climate & 5.03 & 1.53 & SE & 5.68 & 0.81 & $\mathrm{E}$ \\
\hline
\end{tabular}

Note: Int=Interpretation, $\mathrm{SE}=$ Slightly Ethical, $\mathrm{E}=$ Ethical

Taken collectively, the employees' perception of the hotels' ethical climate is highest in the area of social responsibility and lowest in personal morality. It is also interesting to note that employees' perceptions/responses in social responsibility are the most cohesive as supported by the lowest mean score, while their personal morality responses are the most diverse.

The hotels' ethical climate can be improved to a higher level, that is, very ethical. Its customers appreciate a perceived ethical hotel, and the employees are more likely to stay. Ethical standards may help the hotel eliminate uncertainties. The hotel's and employees' perspectives of ethical practices should be aligned to have a productive synergy.

Organizations that adopt an ethical management style are more likely to succeed in the long run (Yener et al., 2012).

Table 1.4. Ethical climate of the hotel employees when taken collectively

\begin{tabular}{lccc}
\hline \multirow{2}{*}{ Factors } & \multicolumn{3}{c}{ Collectively $(\mathrm{n}=152)$} \\
& $\overline{\mathrm{x}}$ & $\mathrm{SD}$ & $\mathrm{Int}$ \\
\hline Social Responsibility & 5.34 & 1.25 & $\mathrm{E}$ \\
Rules and Professional Codes & 5.30 & 1.41 & $\mathrm{E}$ \\
Personal Morality & 5.24 & 1.45 & SE \\
Over-all Ethical Climate & 5.30 & 1.32 & $\mathrm{E}$ \\
\hline
\end{tabular}

Note: Int=Interpretation, $\mathrm{SE}=$ Slightly Ethical, E=Ethical

Job Satisfaction. The older female employees with a longer length of service are more satisfied than their young male counterparts with a shorter service length. Overall, the hotel employees are slightly satisfied with their job.

For the hotel's executives and policy-makers, job satisfaction is a crucial factor for business success. The hotel employee's job satisfaction can still be raised to extremely satisfied. The management may explore various ways of doing this. Improving employee job satisfaction not only decreases turnover also provides guests with better service from the employees.

The satisfaction of employees naturally differs. It is not the same for all individuals since employees desire different things at different times as influenced by their age and sex. The company's ability to satisfy these needs may lead to workers' motivation (Iroegbu, 2015). In the hotel industry, job satisfaction/dissatisfaction may be brought about by effort, policies, salary (da Borralha, de Jesus, 
Pinto, \& Viseu, 2016), and working hours.

Generally, older employees tend to experience higher levels of job satisfaction (Concialdi, 2014; Eleswed \& Mohammed, 2013; Hancer \& George, 2003), which may be due to the perks that come with maintaining a long career, including higher salaries, better benefits, and success in the workplace (Iroegbu, 2015). Older or more experienced employees are more comfortable and tolerant of authority. They may have realistic expectations from their jobs. In contrast, young people have high expectations for their job and the company. However, they learn to adapt their expectations according to reality.

Length of service is also a critical determinant of job satisfaction (Francis, 2015). Employees spend more years in the hotel, the level of psychological attachment and the overall level of job satisfaction increases.

Oshagbemi (2000) pointed out that workers with longer service may experience higher satisfaction because they either have found a job that meets their needs or finds promotion opportunities, leading to higher job satisfaction.

Table 2. Job satisfaction of hotel employees

\begin{tabular}{lllll}
\hline Variable & Grouping & $\bar{x}$ & SD & Verbal Interpretation \\
\hline \multirow{2}{*}{ Age } & Younger & 4.94 & 1.67 & Slightly Satisfied \\
& Older & 5.64 & 0.97 & Satisfied \\
Sex & Male & 4.96 & 1.65 & Slightly Satisfied \\
& Female & 5.52 & 1.15 & Satisfied \\
Length of Service & Shorter & 4.93 & 1.67 & Slightly Satisfied \\
\multirow{2}{*}{ As a whole } & Longer & 5.69 & 0.86 & Satisfied \\
\hline
\end{tabular}

Organizational Commitment. Regardless of age, employees of the hotels are slightly committed. However, they are 'undecided' in the area of affective commitment, which means they are not sure whether they can identify themselves with the goals of the organization and desire to remain a part of the organization.

There is room for the hotel management to improve the organizational commitment of their employees, more particularly on their affective commitment. To address this, the giving of various financial and non-financial incentives may be explored by the management.

Older workers had more experience and spent much time in their current jobs (Dunham, Grube, \& Castaneda,1994), will have fewer job opportunities (Mathieu \& Zajac, 1990), and this leads to a higher commitment to their current jobs than younger workers (Chiew, Foo, Ho, Hu, \& Tan, 2014).

Affective commitment to the hospitality environment is highly desirable. Employees who manifest a high affective commitment to the hospitality company are often more willingly contributing to organizational performance and will do further than what is expected of them by management (Krüger, Wessels, \& Saayman, 2014). Employees who are faithfully committed to their job have a better chance of providing a satisfying experience to guests (Krüger et al., 2014; Lam, Zhang, \& Baum, 2001; Richardson, 2009).

There are several employment options available to older employees (Lam, Zhang, \& Baum, 2001; Mowday, Porter, \& Steers, 1982). Moving away may cost them more than staying (Parasuraman \& Nachman, 1987).

Table 3.1. Organizational commitment of hotel employees when grouped according to age

\begin{tabular}{lccccccc}
\hline \multirow{2}{*}{ Scales } & \multicolumn{3}{c}{ Younger $(\mathrm{n}=85)$} & \multicolumn{3}{c}{ Older $(\mathrm{n}=67)$} \\
& $\overline{\mathrm{x}}$ & SD & Int & $\overline{\mathrm{x}}$ & SD & Int \\
\hline Affective commitment scale & 4.31 & 0.94 & $\mathrm{U}$ & 4.15 & 0.63 & $\mathrm{U}$ \\
Continuance commitment scale & 4.82 & 1.65 & SC & 5.41 & 1.05 & $\mathrm{C}$ \\
Normative commitment scale & 4.50 & 1.23 & SC & 5.01 & 0.70 & SC \\
Over-all organizational commitment & 4.54 & 1.09 & SC & 4.86 & 0.61 & SC \\
\hline
\end{tabular}

Note: Int=Interpretation, $\mathrm{U}=$ Undecided, $\mathrm{SC}=$ Slightly Committed, $\mathrm{C}=$ Committed 
Organizational Commitment of hotel employees, when grouped according to sex, is similar when arranged according to age. Overall, they are slightly committed but are undecided in the aspect of affective commitment.

Knowing this, the management may design training and programs that may help improve the commitment of employees. The undecided affective commitment of employees may mean that their personal goals may not be aligned with that of the hotel or that they may not be aware of the hotel's goals. With this, the management may come up with activities that will improve their affective commitment.

Women reflected higher organizational commitment levels than their male counterparts (Ellemers, de Gilder,\& Van Den Heuvel, 1998; Mitonga-Monga \& Flotman, 2017; Moore \& Moore, 2014). As women's participation rate in the workforce has increased, they had higher levels of organizational commitment and continuance commitment than men (Clayton et al., 2007; Jonathan, Thibeli, \& Darroux, 2013). Khalili and Asmawi (2012) noticed that men's and women's normative commitment differs (Jena, 2015).

Continuance and normative commitment of male and female employees do not differ, but their affective commitment differs, showing men as more affectively committed than women (Jonathan et al., 2013; Labatmedienè, Endriulaitienè, \& Gustainienè, 2007). However, differences were noted among men and women for organizational commitment. Men had higher scores on continuance and normative commitment than women (Deprez, Van den Broeck, Cools, \& Bouckenhoooghe, 2012; Jonathan et al., 2013).

Table 3.2. Organizational commitment of hotel employees when grouped according to sex

\begin{tabular}{lccccccc}
\hline \multirow{2}{*}{ Scales } & \multicolumn{3}{c}{ Male $(\mathrm{n}=74)$} & \multicolumn{4}{c}{ Female $(\mathrm{n}=78)$} \\
& $\overline{\mathrm{x}}$ & SD & $\overline{\mathrm{x}}$ & SD & $\overline{\mathrm{x}}$ & SD \\
\hline Affective commitment scale & 4.16 & 0.79 & $\mathrm{U}$ & 4.32 & 0.85 & $\mathrm{U}$ \\
Continuance commitment scale & 4.87 & 1.60 & SC & 5.28 & 1.26 & SC \\
Normative commitment scale & 4.59 & 1.12 & SC & 4.85 & 0.99 & SC \\
Over-all organizational commitment & 4.54 & 0.98 & SC & 4.82 & 0.84 & SC \\
\hline
\end{tabular}

Note: Int=Interpretation, $\mathrm{U}=$ Undecided, SC=Slightly Committed, C=Committed

Both groups (shorter and longer length of service) are undecided in their affective commitment. However, employees with a shorter length of service are still undecided in their normative commitment. The undecided normative commitment of employees implies that they lack awareness of the hotels' norms and guides. To improve employees' normative commitment with shorter service, the hotel may include in its on-boarding program a detailed presentation of the hotel's policies, procedures, standards, and guidelines, and an understanding check may be done after the training to validate the transfer of knowledge.

Organizational commitment is determined by the type and quality of an employee's job experience (Preethi \& Lourthuraj, 2015) during their business tenure (Meyer \& Allen, 1997). Baron and Greenberg (2004) stated that employees with tenure or seniority and those satisfied with their job performance levels tend to report higher organizational commitment levels than others.

On Affective Commitment, Meyer and Allen gave this example that "positive relationships among tenure and commitment may be due to tenure-related differences in job status and quality (Preethi \& Lourthuraj, 2015).

Table 3.3. Organizational commitment of hotel employees when grouped according to length of service

\begin{tabular}{lccccccc}
\hline \multicolumn{1}{c}{ Scales } & \multicolumn{3}{c}{ Shorter $(\mathrm{n}=89)$} & \multicolumn{3}{c}{ Longer $(\mathrm{n}=63)$} \\
& $\overline{\mathrm{x}}$ & $\mathrm{SD}$ & $\overline{\mathrm{x}}$ & $\mathrm{SD}$ & $\overline{\mathrm{x}}$ & $\mathrm{SD}$ \\
\hline Affective commitment scale & 4.25 & 0.89 & $\mathrm{U}$ & 4.23 & 0.72 & $\mathrm{U}$ \\
Continuance commitment scale & 4.71 & 1.68 & $\mathrm{SC}$ & 5.60 & 0.78 & $\mathrm{C}$ \\
Normative commitment scale & 4.42 & 1.22 & $\mathrm{U}$ & 5.16 & 0.55 & $\mathrm{SC}$ \\
Over-all organizational commitment & 4.46 & 1.08 & $\mathrm{SC}$ & 5.00 & 0.50 & $\mathrm{SC}$ \\
\hline
\end{tabular}

Note: Int=Interpretation, U=Undecided, SC=Slightly Committed, C=Committed 
When taken collectively, the employees are slightly committed but undecided regarding their affective commitment. A hotel's productivity depends on the employee's organizational commitment, behaviors, and attitudes, which means that the management has to be creative in designing programs to improve their commitment.

Affective commitment define as the employee's emotional attachment to, identification with, and involvement in the organization (Preethi \& Lourthuraj, 2015).A high level of affective commitment is related to low employee turnover, low absenteeism, and improved job performance; hence employees with a strong affective commitment continue employment with the company because they want to do so (Igella, 2014). An affectively committed employee desires to stay and firmly identifies with the goals of the organization. This employee commits to the company because he/she "wants to" (Allen \& Meyer, 1990).

Continuance commitment describes individuals' need to endure with the organization resulting from her/his recognition of the costs like tenure, pay, benefits, vesting of pensions, family commitment (Loi, Hang-yue, \& Foley, 2006) and knowledge of the costs associated with leaving the organization (Igella, 2014). Employees whose main link to the organization is based on continuance commitment remain because they need to do so (Loi et al., 2006).

On the other hand, normative commitment indicates a person's feeling of obligation to sustain organizational membership because he/she understands it is decently right to be loyal to and stay in the organization (Coyle-shapiro \& Morrow, 2006). Furthermore, the individual commits to and remains with an organization because of feelings of obligation, the last component of organizational commitment (Preethi \& Lourthuraj, 2015). Although normative commitment is generally recognized as a salient dimension of employee commitment, it is substantially inter-related with affective commitment (Coyleshapiro \& Morrow, 2006). These feelings of obligation in normative commitment may arise from stress on an individual before and after entering an organization (Preethi \& Lourthuraj, 2015).

Table 3.4. Organizational commitment of hotel employees when taken collectively

\begin{tabular}{lccc}
\hline \multirow{2}{*}{ Scales } & \multicolumn{3}{c}{ Taken Collectively $(\mathrm{n}=152)$} \\
& $\overline{\mathrm{x}}$ & $\mathrm{SD}$ & $\mathrm{Int}$ \\
\hline Affective commitment scale & 4.24 & 0.82 & $\mathrm{U}$ \\
Continuance commitment scale & 5.08 & 1.44 & $\mathrm{SC}$ \\
Normative commitment scale & 4.73 & 1.06 & $\mathrm{SC}$ \\
Over-all organizational commitment & 4.68 & 0.92 & SC \\
\hline
\end{tabular}

Note: Int=Interpretation, $\mathrm{U}=$ Undecided, SC=Slightly Committed, C=Committed

\section{Relationship among ethical climate, job satisfaction, and organizational commitment}

Results reveal a significant relationship among the three variables as supported by $p$-values which, are all less than 0.05 . The result confirms the researchers' proposition that the hotel's ethical climate results in job satisfaction and organizational commitment with an ethical climate resulting in slightly satisfied and slightly committed employees. This implies that if the hotel can improve its ethical climate, its job satisfaction and organizational commitment will also improve. Training and other activities geared toward improving the climate, satisfaction, and commitment may be designed by the hotel management.

Ethical climate influences job satisfaction (Anaza et al., 2015; Jaramillo et al., 2006; Peterson, Park, \& Seligman, 2005; Pettijohn et al., 2008) and organizational commitment (Newman et al., 2017). An organization can influence all facets of job satisfaction by manipulating ethical climate except compensation (Okoli \& Monanu, 2016).

There is a positive relationship between an organization's ethical climate and organizational commitment (Unal, 2012). Organizations that exhibit strong ethical values may benefit from having more committed employees (Vitell \& Hidalgo, 2006). Schwepker Jr (2001) found a positive relationship between salespeople's perception of the organization's ethical climate and organizational commitment. 
Table 4. Relationship among ethical climate, job satisfaction, and organizational commitment

\begin{tabular}{lccc}
\hline Variables & & Job satisfaction & Organizational commitment \\
\hline \multirow{2}{*}{ Ethical Climate } & $\mathrm{r}$ & $0.897^{* *}$ & $0.843^{* *}$ \\
& $\mathrm{p}$-value & 0.000 & 0.000 \\
& $\mathrm{n}$ & 152 & 152 \\
\hline
\end{tabular}

Note: ${ }^{* *}$ The relationship is significant at 0.05 .

\subsection{Conclusion}

The hotels have an ethical climate, slightly satisfied, and slightly committed employees. This result indicates that the employees observe and follow workplace policies and guidelines, exude appropriate conduct, and reflect morally proper actions. However, there is still a big room for improvement as the ethical climate can still be raised to an extremely ethical level. The same may be applied to job satisfaction and organizational commitment. However, the hotel's climate is not the sole responsibility of the hotel owners or management. Relationships among employees also provide critical insight into workplace norms, guides, and the current organizational climate. All hotel employees must clearly understand the importance of this ethical climate to contribute to the hotel's organizational performance.

Employees who are slightly satisfied with their jobs may be considered a potential threat to the smooth hotel's operation. It may trigger them to find more satisfying jobs somewhere. The hotel management may explore various ways of improving the job satisfaction of hotel employees to address their job concerns.

Having slightly committed employees may also put the hotels' operation at stake, especially if employees are confronted with stressful situations. Their first option may be to leave their work. The loyalty and performance of the employees in the organization are unpredictable.

The ethical climate, job satisfaction, and organizational commitment are significantly related. Ethical climate in this study presents to hotel managers insights on how ethical practices can help the hotel improve employee satisfaction and commitment. With the hotels' norms and guides specifying rules and regulations to regulate employee behavior and practices, managers must ensure that such norms contribute to job satisfaction and organizational commitment.

\section{REFERENCES}

Abdullah, A. (2011). Evaluation of Allen and Meyer's Organizational Commitment Scale: A Cross-Cultural Application in Pakistan. Journal of Education and Vocational Research, 1(3), 80-86. https://doi.org/10.22610/jevr.v1i3.13

Al-Jabri, B. \& Ghazzawi, I. (2019). Organizational Commitment : A Review of the Conceptual and Empirical Literature and a Research Agenda. International Leadership Journal, 11(March), 78-119.

Allen, N. J. \& Meyer, J. P. (1990). The measurement and antecedents of affective, continuance, and normative commitment to the organization. Journal of Occupational Psychology, 63(1), 1-18. https://doi.org/10.1111/j.2044-8325.1990.tb00506.x

Allen, N. J. \& Meyer, J. P. (1990). The Measurement and Antecedents of Affective, Continuance, and Normative Commitment to the Organization. Journal of Occupational Psychology, 63, 1-18.

Anaza, N. A., Rutherford, B., Rollins, M., \& Nickell, D. (2015). Ethical climate and job satisfaction among organizational buyers: An empirical study. Journal of Business and Industrial Marketing, 30(8), 962-972. https://doi.org/10.1108/JBIM-03-2014-0047

Aprilliani, D., Anggaraini, R., \& Anwar, C. (2014). The Effect of Organization Ethical Culture and Ethical Climate on Ethical Decision Making of Auditor with Self Efficacy as Moderating. Review of Integrative Business and Economics, 4(1), 226-244.

Armstrong, A. \& Francis, R. (2008). An Ethical Climate is a Duty of Care Introduction: What do We Mean by a Duty of Care? Journal of Business Systems, Governance, and Ethics, 3(3), 15-20. Retrieved from http://citeseerx.ist.psu.edu/viewdoc/ download? doi $=10 \cdot 1 \cdot 1 \cdot 669 \cdot 146 \&$ rep $=$ rep $1 \&$ type $=$ pdf

Arulrajah, A. A. (2015). Contribution of human resource management in creating and sustaining ethical climate in the organizations. Sri Lankan Journal of Human Resource Management, 5(1), 31-44. https://doi.org/10.4038/sljhrm.v5i1.5626

Ayre, C. \& Scally, A. J. (2014). Critical values for Lawshe's content validity ratio: Revisiting the original methods of calculation. Measurement and Evaluation in Counseling and Development, 47(1), 79-86. https://doi.org/10.1177/0748175613513808

Azeez, R. O., Jayeoba, F., \& Adeoye, A. O. (2016). Job satisfaction, organizational commitment, turnover intention, and ... Journal of Management Research, 8(2), 102-114.

Baron, R. A. \& Greenberg, J. (2004). Behavior in Organizations: Understanding and Managing the Human Side of Work. Boston, MA.

Bernaldez, E. A. \& Gempes, G. P. (2016). The Mediating effect of Conflict Management styles of School Heads on the relationship between Ethical Climate and Organizational Commitment among Public Elementary Schools in region XI. International Journal of Management Excellence, 7(1), 743-750. https://doi.org/10.17722/ijme.v7i1.257

Bernerth, J. B. \& Walker, H. J. (2009). The propensity to trust and the impact on social exchange: An empirical investigation. Journal of Leadership and Organizational Studies, 15(3), 217-226. https://doi.org/10.1177/1548051808326594

Brunton, M. \& Eweje, G. (2012). Teaching Ethics: The Role of Culture in Ethical Perceptions. Journal of Business Ethics Education, 9, 7-26. https://doi.org/10.5840/jbee201292 
Cheteni, P. \& Shindika, E. S. (2017). Ethical Leadership in South Africa and Botswana. BAR-Brazilian Administration Review, 14(2).

Chiaburu, D. S. \& Harrison, D. A. (2008). Do Peers Make the Place? Conceptual Synthesis and Meta-Analysis of Coworker Effects on Perceptions, Attitudes, OCBs, and Performance. Journal of Applied Psychology, 93(5), 1082-1103. https://doi.org/10.1037/00219010.93.5.1082

Chiew, M. S., Foo, M. Y., Ho, S. L., Hu, S. P., \& Tan, S. Z. (2014). A study on the relationship between organizational commitment and intention to leave: Age as the moderator. Universiti Tunku Abdul Rahman.

Chiu, W. Y. B. \& Ng, F. F. (2013). Improvement of job satisfaction and organizational commitment through workgroup identification: An examination of the quantity surveyors in Hong Kong. Australasian Journal of Construction Economics and Building, 13(3), 80-95. https://doi.org/10.5130/ajceb.v13i3.3316

Chou, P. (2016). Social Exchange Relationship and Employee Attitudes toward Newly Introduced Information System. European Scientific Journal, ESJ, 12(25), 163-184. https://doi.org/10.19044/esj.2016.v12n25p163

Clayton, B., Petzall, S., Lynch, B., \& Margret, J. (2007). An Examination of the Organisational Commitment of Financial Planners. International Review of Business Research Papers, 3(1), 60-72.

Concialdi, C. (2014). The role of gender, age, occupational position, and job performance on employees' job satisfaction. DBS School of Arts. Retrieved from https://pdfs.semanticscholar.org/2570/346d1783f727f6ed76b5b90385516bc00904.pdf

Costouros, T. (2017). Gender and ethical decision-making in the general insurance industry. Journal of Behavioral Studies in Business, 9(June), 1-24

Coyle-shapiro, J. A. \& Morrow, P. C. (2006). Organizational and Client Commitment among Contracted Employees. Journal of Vocational Behavior, 68(3), 416-431.

Cremer, D. De, Mayer, D. M., \& Schminke, M. (2010). Guest Editors' Introduction On Understanding Ethical Behavior and Decision Making: A Behavioral Ethics Approach David. Business Ethics Quarterly, 20(1), 1-6.

Cropanzano, R., Anthony, E. L., Daniels, S. R., \& Hall, A. V. (2017). Social exchange theory: A critical review with theoretical remedies. Academy of Management Annals, 11(1), 1-38. https://doi.org/10.5465/annals.2015.0099

Cropanzano \& Mitchell. (2005). Social exchange theory: An interdisciplinary review. Journal of Management, 31(6), 874-900. https:// doi.org/10.1177/0149206305279602

Cullen, J. B., Parboteeah, K. P., \& Victor, B. I. (2003). The Effects of Ethical Climates on Organizational Commitment : A Two-Study Analysis The effects of ethical climates on organizational commitment : A two-study ana ... John B Cullen; K Praveen Parboteeah ; Bart Victor. Journal of Business Ethics, (January). https://doi.org/10.1023/A

Cullen, J. B., Victor, B., \& Bronson, J. W. (1993). The Ethical Climate Questionnaire: An Assessment of its Development and Validity. Psychological Reports, 73(2), 667-674. https://doi.org/10.2466/pr0.1993.73.2.667

da Borralha, S., de Jesus, S. N., Pinto, P., \& Viseu, J. (2016). Job Satisfaction in Hotel Employees: A Systematic Review of the Literature. Journal of Spatial and Organizational Dynamics, 4(1), 4-20.

Dawson, L. M. (1995). Women Men Morality Ethics.Pdf. Business Horizons, 38(4), 61-68.

Deprez, J., Van den Broeck, H., Cools, E., \& Bouckenhoooghe, D. (2012). Gender Differences in Commitment To Change: Impacted By Gender or By Being Part of a Minority Group?

Dunham, R. B., Grube, J. A., \& Castaneda, M. B. (1994). Organizational commitment: The utility of an integrative definition. Journal of Applied Psychology, 79(3), 370.

Eleswed, M. \& Mohammed, F. (2013). Job satisfaction and organizational commitment: A correlational study in Bahrain. International Journal of Business, Humanities, and Technology, 3(5), 44-53.

Ellemers, N., de Gilder, D., \& Van Den Heuvel, H. (1998). Career-oriented versus team-oriented commitment and behavior at work. Journal of Applied Psychology, 83(5), 717.

Emmanuel, I. \& Oge, G. (2016). An Exploration of Ethical Climate and Job Satisfaction in Selected Manufacturing Organisations. International Journal of Research in Management, Economics, and Commerce, 6(9), 11-21.

Francis, U. C. (2015). Influence of gender, age, and job tenure on job satisfaction of medical and non-medical employees of a university teaching hospital in Lagos, Nigeria. African Journal For The Psychological Study Of Social Issues, 18(3), 96-107. https://doi. org/10.1017/СBO9781107415324.004

Graham, J. (2014). The Role of Corporate Culture in Business Ethics. Vysoká Škola Manažmentu, Tren. Retrieved from https://www. theseus.fi/bitstream/handle/10024/147515/ThesisFinished.pdf?sequence=1\&isAllowed =y

Hancer, M. \& George, R. T. (2003). Job Satisfaction Of Restaurant Employees: An Empirical Investigation Using The Minnesota Satisfaction Questionnaire. Journal of Hospitality and Tourism Research, 27(1), 85-100. https://doi.org/10.1177/1096348002238882

Hwang, J. \& Seo, S. (2016). A critical review of research on customer experience management: Theoretical, methodological, and cultural perspectives. International Journal of Hospitality \& Tourism Administration, 28(10), 2218-2246.

Igella, R. (2014). Factors influencing employee commitment: A case of Kenya civil aviation authority. United States International University.

Iroegbu, M. (2015). Do Age and Gender Have Anything to Do with Job Satisfaction: A Practical Outlook on the Nigerian Public Sector. American Journal of Applied Psychology, 4(4), 111-114. https://doi.org/10.11648/j.ajap.20150404.15

Ismail, S. (2015). Effects of ethical climate on organizational commitment, professional commitment, and job satisfaction of auditor in Malaysia. Gadjah Mada International Journal of Business, 17(2), 139-155. https://doi.org/10.22146/gamaijb.6907

Jaramillo, F., Mulki, J. P., \& Solomon, P. (2006). The Role of Ethical Climate on Salesperson â€ ${ }^{\text {TM }}$ s Role Stress, Job Attitudes, Turnover Intention, and Job Performance. Journal of Personal Selling and Sales Management, 26(3), 271-282.

Jaros, S. (2007). Meyer and Allen Model of Organizational Commitment : Measurement Issues, 7-26.

Jena, R. K. (2015). An assessment of demographic factors affecting organizational commitment among shift workers in India. Management-Journal of Contemporary Management Issues, 20(1), 59-77.

Jonathan, H. (2013). Perceived job satisfaction and its impact on Organizational Commitment: An empirical study of public secondary school teachers in Dodoma, Tanzania. IOSR Journal of Business and Management, 13(3), 41-52. https://doi. org/10.9790/487x-1334152

Jonathan, H., Thibeli, M., \& Darroux, C. (2013). Impact investigation of organizational commitment on the intention to leave of public secondary school teachers in Tanzania. Developing Country Studies, 3(11), 78-92.

Karatepe, O. M. (2013). Inking Perceived Ethical Climate to Performance Outcomes: The mediating role of Job Embeddedness. Economic Research-Ekonomska Istraživanja, 26(4), 77-90. https://doi.org/10.1080/1331677X.2013.11517631

Khalili, A. \& Asmawi, A. (2012). Appraising the Impact of Gender Differences on Organizational Commitment: Empirical Evidence from a Private SME in Iran. International Journal of Business and Management, 7(5), 100-110. https://doi.org/10.5539/ijbm.v7n5p100

Kim, G., Ro, H., Hutchinson, J., \& Kwun, D. J. (2014). The effect of jay-customer behaviors on employee job stress and job satisfaction. International Journal of Hospitality \& Tourism Administration,15(4), 394-416.

Kim, N. Y. \& Miller, G. (2008). Perceptions of the ethical climate in the Korean tourism industry. Journal of Business Ethics, 82(4), 941-954.

Kong, H., Cheung, C., \& Qiu Zhang, H. (2010). Career management systems: what are China's state-owned hotels practising? 
International Journal of Contemporary Hospitality Management,22(4), 467-482.

Krüger, S., Wessels, W., \& Saayman, M. (2014). Association between age, critical skills, and work perspectives. African Journal of Hospitality, Tourism and Leisure, 3(1), 1-20. Retrieved from www.ajhtl.com

Kumar, R., Ramendran, C., \& Yacob, P. (2012). A Study on Turnover Intention in Fast Food Industry: Employees' Fit to the Organizational Culture and the Important of their Commitment. International Journal of Academic Research in Business and Social Sciences, 2(5), 9-42.

Labatmedienè, L., Endriulaitienè, A., \& Gustainienè, L. (2007). Individual correlates of organizational commitment and intention to leave the organization. Baltic Journal of Management, 2(2), 196-212.

Lam, T., Zhang, H., \& Baum, T. (2001). An investigation of employees' job satisfaction: the case of hotels in Hong Kong. Tourism Management, 22(2), 157-165.

Loi, R., Hang-yue, N., \& Foley, S. (2006). Linking employees' justice perceptions to organizational commitment and intention to leave: The mediating role of perceived organizational support. Journal of Occupational and Organizational Psychology, 79(1), 101-120. https://doi.org/10.1348/096317905X39657

Longenecker, J. G., Moore, C. W., Petty, J. W., Palich, L. E., \& McKinney, J. A. (2006). Ethical attitudes in small businesses and large corporations: Theory and empirical findings from a tracking study spanning three decades. Journal of Small Business Management, 44(2), 167-183.

Ma'amor, H., Ann, H. J., Munir, R. I. S., \& Hashim, N. (2013). Average concept of crossover operator in real coded genetic algorithm. In International Proceedings of Economics Development and Research (Vol. 56, pp. 134-138). https://doi.org/10.7763/IPEDR

Martin, K. D. \& Cullen, J. B. (2006). Continuities and extensions of ethical climate theory: A meta-analytic review. Journal of Business Ethics, 69(2), 175-194. https://doi.org/10.1007/s10551-006-9084-7

Mathieu, J. E. \& Zajac, D. M. (1990). Mathieu-Zajac-Oc-Metaanalyse-0360.Pdf. Psychological Bulletin, 108(2), 171-194

Mayer, D. M., Nurmohamed, S., Treviño, L. K., Shapiro, D. L., \& Schminke, M. (2013). Organizational Behavior and Human Decision Processes Encouraging employees to report unethical conduct internally: It takes a village. Organizational Behavior and Human Decision Processes, 121(1), 89-103. https://doi.org/10.1016/j.obhdp.2013.01.002

Mayer, D. M., Nurmohamed, S., Treviño, L. K., Shapiro, D. L., \& Schminke, M. (2013). Encouraging employees to report unethical conduct internally: It takes a village. Organizational Behavior and Human Decision Processes, 121(1), 89-103.

Mc Danel de García, M. A. (2013). Enhancing Moral and Ethical Judgment through the Use of Case Histories: An Ethics Course for Preservice Teachers 1. Gist Education and Learning Research Journal, 7, 93-114.

Meyer, J. P. \& Allen, N. J. (1997). Commitment in the workplace: Theory, research, and application. Sage Publications, Inc.

Meyer, J. P., Allen, N. J., \& Smith, C. A. (1993). Commitment to organizations and occupations: Extension and test of a three-component conceptualization. Journal of Applied Psychology, 78(4), 538.

Mitonga-Monga, J. \& Flotman, A. P. (2017). Gender and work ethics culture as predictors of employees ' organizational commitment. Journal of Contemporary Management, 14, 270-290.

Moore, H. L. \& Moore, W. (2014). The effect of ethical climate on the organizational commitment of faculty members. Journal of Academic and Business Ethics, 9(12), 1-15.

Mowday, R. T., Porter, L. W., \& Steers, R. (1982). Organizational linkages: The psychology of commitment, absenteeism, and turnover.

Mujtaba, B. G., Cavico, F. J., \& Sungkhawan, J. (2011). Business Ethics of Government Employees and Future Lawyers in Thailand: a Study of Age, Gender, Management Experience, and Education. International Business Research, 4(1), 16-27. https://doi.org/10.5539/ ibr.v4n1p16

Nafei, W. A. (2015). Ethical climate as a moderator of the relationship between job satisfaction and organizational commitment: evidence from industrial companies in Egypt. International Journal of Investment Management and Financial Innovations, 1(1), $1-15$

Nafie, W. A. (2015). Ethical climate as a moderator of the relationship between job satisfaction and organizational commitment: evidence from industrial companies in Egypt. International Journal of Investment Management and Financial Innovations, 1(1), $1-15$.

Newman, A., Round, H., Bhattacharya, S., \& Roy, A. (2017). Ethical Climates in Organizations: A Review and Research Agenda. Business Ethics Quarterly, 27(4), 475-512. https://doi.org/10.1017/beq.2017.23

O'Reilly, C. \& Chatman, J. (1986). Organizational Commitment and Psychological Attachment. The Effects of Compliance, Identification, and Internalization on Prosocial Behavior. Journal of Applied Psychology, 71(3), 492-499. https://doi.org/10.1037/00219010.71 .3 .492

Okoli, I. E. \& Monanu, O. G. (2016). An Exploration of Ethical Climate and Job Satisfaction in Selected Manufacturing Organisations. International Journal of Research in Management, Economics, and Commerce, 6(9), 11-21.

Oshagbemi, T. (1999). Overall job satisfaction: How good are single versus multiple-item measures? Journal of Managerial Psychology.

Oshagbemi, T. (2000). s length of service related to the level of job satisfaction? International Journal of Social Economics, 27(3), 213-226.

Parasuraman, S. \& Nachman, S. A. (1987). Correlates of Organizational and Professional Commitment: The case of musicians in symphony orchestras. Group \& Organization Studies, 12(3), 287-303. https://doi.org/10.1177/105960118701200305

Peterson, C., Park, N., \& Seligman, E. P. (2005). Orientations to happiness and life satisfaction: The full life versus the empty life. Journal of Happiness Studies, 6(1), 25-41. https://doi.org/10.1007/s10902-004-1278-z

Peterson, D. K. (2002). Deviant Workplace Behavior and the Organization's Ethical Climate. Journal ofBusiTiess and Psychology, 17(1), 47-61. https://doi.org/10.1023/A

Pettijohn, C., Pettijohn, L., \& Taylor, A. J. (2008). Salesperson perceptions of ethical behaviors: Their influence on job satisfaction and turnover intentions. Journal of Business Ethics, 78(4), 547-557.

Potocan, V., Mulej, M., \& Nedelko, Z. (2013). The Influence of Employees' Ethical Behavior on Enterprises' Social Responsibility. Systemic Practice and Action Research, 26(6), 497-511. https://doi.org/10.1007/s11213-013-9299-3

Preethi, B. \& Lourthuraj, S. A. (2015). Organizational Commitment and Its Impact on Employee Behavior. Journal Impact Factor, 6(1), 394-400.

Punch, K. F. (2013). Introduction to social research: Quantitative and qualitative approaches. SAGE Publications.

Putra, A. A. G., Dharmanegara, I. B. A., \& Yas, P. N. S. (2019). Analyzing the Relationship of Ethical Work Climate, Job Satisfaction, Organizational Commitment, and Job Performance in Tabanan University, Bali. International Journal of Academic Research in Business and Social Sciences, 9(9), 1100-1115. https://doi.org/10.6007/ijarbss/v9-i9/6405

Richardson, S. (2009). Undergraduates' perceptions of tourism and hospitality as a career choice. International Journal of Hospitality Management, 28(3), 382-388. https://doi.org/10.1016/j.ijhm.2008.10.006

Rubel, M. R. B., Kee, D. M. H., Quah, C. H., \& Rimi, N. N. (2017). Ethical Climate and Employee Turnover Intention in the Ready-Made Garment Industry of Bangladesh. Global Business and Organizational Excellence, 36(2), 61-73. https://doi.org/10.1002/joe.21770 
Schwepker Jr, C. H. (2001). Ethical climate's relationship to job satisfaction, organizational commitment, and turnover intention in the salesforce. Journal of Business Research, 54(1), 39-52.

Stanley, T. (2016). Work environments, creative behaviours, and employee engagement. The Queensland University of Technology.

Treviño, L., Butterfield, K. D., \& McCabe, D. L. (1998). The ethical context in organizations: Influences on employee attitudes and behaviors. Business Ethics Quarterly, 8(3), 447-476. https://doi.org/10.2307/3857431

Uen, J.-F., Wu, T., \& Tsai, H.-C. (2011). Ethical Climate and its Relationship to Ethical Behavior and Ethical Mechanisms. Chiao Da Management Review, 31(2), 33-60.

Unal, O. F. (2012). Relationship between organizational commitment and ethical climate: The mediating role of job satisfaction dimensions (a study in a group of companies in Turkey). Journal of WEI Business and Economics, 1(1), 92-105. Retrieved from http://www.westeastinstitute.com/journals/wp-content/uploads/2013/02/ZG12-289-Omer-Faruk-Unal-Relationship-BetweenOrganizational-Commitment-And-Ethical-Climate-The-Mediating-Role-Of-Job-Satisfact1.pdf

Venezia, G., Nti-Osei, O. A., Venezia, C., \& Hsueh, C. H. (2017). The impact of gender on ethical work climates: a cross-cultural comparison of business school faculty. Business Education \& Accreditation, 9(1), 23-33.

Verschoor, C. C. (2013). Ethical behavior differs among generations: a new study shows that the ethical behavior of younger workers differs from that of older generations. Business leaders should strengthen their ethics and compliance programs to address these differences. Strategic Finance, 95(2), 11-14.

Vitell, S. J. \& Hidalgo, E. R. (2006). The impact of corporate ethical values and enforcement of ethical codes on the perceived importance of ethics in business: A comparison of the U.S. and Spanish managers. Journal of Business Ethics, 64(1), 31-43. https://doi. org/10.1007/s10551-005-4664-5

Vrdoljak Raguž, I. \& Matić, M. (2016). Business students' attitudes towards business ethics: Evidence from Croatian universities. Management: Journal of Contemporary Management Issues, 21((Special Issue)), 189-205.

Westermann-Behaylo, M. (2010). The relationship between corporate ethical climate and stakeholder management. The George Washington University.

Yeh, Y. (1999). Employee satisfaction of hotel industry: A Case study of the Grand Hotel Taipei. Rochester Institute of Technology.

Yener, M., Yaldıran, M., \& Ergun, S. (2012). The Effect of Ethical Climate on Work Engagement. Procedia - Social and Behavioral Sciences, 58, 724-733. https://doi.org/10.1016/j.sbspro.2012.09.1050

\section{Correspondence:}

CARMEN C. MENES

ccmenes@gmail.com

https://orcid.org/0000-0001-8540-7595

ISMAEL A. HAGUISAN III

ihaguisan3@gmail.com

https://orcid.org/0000-0001-6206-8957 